\title{
TOPIC-BASED ESP MATERIALS FOR VOCATIONAL SCHOOL
}

\author{
Banun Havifah Cahyo Khosiyono \\ Mahasiswa S3 Ilmu Pendidikan Bahasa Uiversitas Negeri Yogyakarta, Indonesia
}

\begin{abstract}
This paper aims to describe how to design topic-based ESP materials for Vocational School. ESP is an approach to language teaching whichaims to meet the needs of particular learners. Moreover, topic-based ESP materials for Vocational School should be designeddepend on the needs of the learners in relation to their future or present jobs. The topic-based ESP materials should focus on the appropriate topics and include tasks and activities that practice the target skills areas.
\end{abstract}

Key words: design, topic-based, ESP materials, Vocational School

\section{INTRODUCTION}

Must be successfully reformation of Indonesia as anindustrial country had become a consideration inestablishing a Vocational School or SMK (Sekolah Menengah Kejuruan) as a part of vocational education. Althoughit is still in a process of adjustment with overseastechnology, Indonesia needs professional workers,particularly skilled and managerial ones (Schippers and Patriana, 1994: 4). In modern and plural great industrialsociety, job divisions of the society cover a number ofaspects which are included in complex structures. Thedemands for interest, capability, work, individuals' potential and workers must be considered in deciding thetarget ('who does, what, where and when?'). As a result,formal education system comes in relation to guaranteefor fulfilling the demands for job seekers.

Permendikbud No. 70 Year 2013 mentions that majors at Vocational School include Technology and Engineering, Information and Communication technology, Health; Agribusiness and Agro-technology,Fisheries and Maritime Affairs, Business and Management, Tourism, Arts and Crafts, Performing Arts. Therefore, the learning process of vocational school students is particularly purposes at preparing thegraduates to gain supporting skills of any careers andability of self-improvement appropriate with their majors in vocational schools.In response, the training andeducation program in vocational school are dividedinto three groups. There are Kelompok Mata Pelajaran Wajib A, Kelompok Pelajaran Wajib B, and Kelompok Mata Peminatan (Kejuruan). In this case, English subject in vocational school, which is included into Kelompok Pelajaran Wajib A, teach for 36 hours persemester for X grade, XI and XII grade. Each season runsfor 45 minutes.

However, in 2013 Curriculum English subject forSMA/MA and SMK/MAK has equal contents whichconsist of content of curriculum (KI/KD) and content ofsubject (Kemendikbud, 2012: 15).Teaching English at vocational school is a process ineducation world that prepares trainees for jobs that arebased on manual 
or practical activities, traditionally nonacademic, and totally related to a specific occupation orvocation. The ultimate aim of teaching English at the vocational school is to prepare students to master the English skills and knowledge base which willsupport the achievement of competencies and skills toimplement the program expertise and skills mastery of English skills in oral and writtencommunication at an advanced level (Kemendikbud, 2013: 9).

Yuana and Kurniasih (2013) suggest that in aneducational setting, a learners' needs analysis supportsstudents categorize where they are in terms of theirknowledge, skills and competences, versus where theywish to be and their learning goals. By knowing exactlywhat they learn in school will be beneficial for their future, therefore, it could motivatethem to learn English betterbecause they have their purpose of learning. Moreover, English in vocational school should be directed atEnglish for Specific Purposes (ESP) since it has specificcharacteristics. Therefore, English materials in vocational school should be diverse based on thestudent's need to learn English appropriate with their future jobs. Moreover, this paper aims to describe how to design topic-based ESP materials for Vocational school.

\section{ENGLISH FOR SPECIFIC PURPOSE}

The teaching of ESP is in many ways similar to the teaching of Englishin general although there are features that are typically in different specialized subjects. According to Hutchinson and Waters (2008), the approach to ESP should be based on the principles of effective learning and teaching language for general purposes. They further state that in the past, the teaching of ESP wasprimarily concerned with linguistic aspects of the language. Now, it has shiftedtowards developing communication skills, and learning is very much directed byspecific learner's needs for mastering the language.

Crokers ( in Budianto, 2003:12) also says that ESPcourses are similar to language instruction in general, which puts more emphasison language use. The obvious difference is in the focus of interest. While Englishfor general purposes emphasizes on language proficiency, ESP coursesemphasize on something outside of the language through the medium oflanguage. This statement views language mastery as necessary prerequisite skillsthat the learners must have in order to function well in their future workplace.Unlike English courses in general, an ESP courses as a means not an end initself. In addition, ESP should be simply seen as an approach to teaching.

Hutchinson and Water $(2008,21)$ say that ESP is an approach to language teaching whichaims to meet the needs of particular learners. The guiding principle of ESP is derived from what they suggest that if language varies from one situation of use to another, it should be possible todetermine the features of specific situation and then make these features the basis of the learners'course. This notion proposes that the nature of ESP is context-specific and specificallysituated in awide range of specialist or disciplinary discourse communities.

Drawing on Dudley-Evans and St. John (1998: 4-5), ESP has the following characteristics. 
1. ESP programs are designed to cater to the discipline- or vocation-specific needs of learners with a different level of language ability to communicate for work or study purposes in specific disciplines.

2. The programs are informed by a theoretical orientation (approach) along with instructional design (design and procedure).

3. ESP materials and methods are developed or adapted to provide learners with needsresponsive instruction.

4. ESP centers on a myriad of disciplinary knowledge, language, genres, discourses as social practices, and situational specificity.

5. Both language and activities are appropriate to particular disciplines.

6. In ESP programs, students learn knowledge or concepts from their discipline or specialization.

7. These programs require the students to learn to recognize how language operates within genres and sub-genres in this discipline or specialization.

From both wide-angled and narrow-angled perspectives, Basturkmen (2010: 6) categorizes thedifferent ESP branches as follows.

Table 1 Basturkmen's Classification of ESP Branches

\begin{tabular}{|c|c|c|}
\hline Branches & Sub Branches & Examples \\
\hline $\begin{array}{l}\text { English for } \\
\text { Purposes (EAP) }\end{array}$ & $\begin{array}{ll}\text { - } & \begin{array}{l}\text { English for } \\
\text { Academic }\end{array} \\
\text { (EGAP) } & \\
\text { - } & \begin{array}{l}\text { English for } \\
\text { Academic } \\
\text { (ESAP) }\end{array} \\
\text { Purposific } \\
\end{array}$ & $\begin{array}{l}\text { English for academic } \\
\text { writing } \\
\text { English for law studies }\end{array}$ \\
\hline $\begin{array}{l}\text { English for Professional } \\
\text { Purposes (EPP) }\end{array}$ & $\begin{array}{ll}\text { - } & \text { English for } \\
\text { GeneralProfessional } \\
\text { Purposes(EGPP) } \\
\text { English for } \\
\text { SpecificProfessional } \\
\text { Purposes(ESPP) }\end{array}$ & $\begin{array}{l}\text { English for the health care } \\
\text { sector } \\
\text { English for nursing }\end{array}$ \\
\hline $\begin{array}{lr}\text { English for } & \text { Occupational } \\
\text { Purposes } & \text { (EOP) }\end{array}$ & $\begin{array}{ll}\text { - } & \text { English for General } \\
\text { Occupational Purposes } \\
\text { (EGOP) } \\
\text { - English for Specific } \\
\text { Occupational Purposes } \\
\text { (ESOP) }\end{array}$ & $\begin{array}{l}\text { English for the hospitality } \\
\text { industry } \\
\text { English for hotel } \\
\text { Receptionists }\end{array}$ \\
\hline
\end{tabular}

This broad classification shows that ESP has a range of areas or domains. These areas haveparticular specialized or disciplinary knowledge, language, genres, social practices, and discourses, which are not static because disciplinary and specialized discourse communities continue to evolve, and their communicative interests and needs always change. Thus, the specificity of ESP lies inspecific groups of learners with different language abilities, specific needs 
and language, particulardisciplinary knowledge, particular genres and discourses, community-based social practices, andparticular contexts of situation.

\section{VOCATIONAL ENGLISH}

Of Basturkmen's (2010) ESP Branches, the one area of ESP, which remains rarely explored in theESP literature, is English for Vocational Purposes (EVP) or Vocational English (VE), though somestudies have reported vocationally-oriented language learning (hereafter VOLL) or VE programs. In these studies,English language programs are contextualized within the process of learning vocationalcompetencies, and English language skills are viewed as social practices and specific disciplines asdynamic because the actual use of the language happens in authentic environments, in whichstudents engage (Platt, 1996). In other words, the emphasis is on using the language to learn ormake sense of vocational content. In addition, vocational socialization (inducting learners into theculture of their chosen vocations or disciplines) and literacies (language as dynamic social practice)are key components of VOLL.

The issue of VE or VOLL in the context of English as a second language (ESL) has a history datingback to the 1970s (Gage \& Prince, 1982). Since its inception, this type of ESP has been designed forlanguage minority or immigrant learners in adult education programs and for school leavers insecondary and postsecondary education to prepare them for possible study and employment opportunities (Platt, 1996). Within the framework of VOLL, VE refers to a program -enablinglearners to communicate not only in the (future) workplace but also provides a more generalcompetence that integrates vocational, linguistic, and social skills (Egloff in Vogt and Kantelinen, 2013: 64). Further, it involves the vocational aspects of the learner's life but is notlimited to the immediate occupational demands of work (Vogt and Kantelinen, 2013: 65). In thesecondary education sector, VOLL is designed for learners who are prepared for a range of semiskilled employment or occupations, which require English as an additional competence (Vogt andKantelinen, 2013). Thus, in the educational sphere such as in the secondary vocational education, VE has been institutionally recognized.

In many ESP studies, the context of EVP or VE remains institutionally situated in higher education(e.g., colleges and universities). Although some ESP scholars categorize EVP into EOP, VE can becategorized as a kind of ESP or a content-based language learning program, in which the specificlanguage demands of students' vocational areas need to be learned (Platt, 1996). Following this argument, Widodo (2014) adds one more category to Basturkmen's classification of ESP branches as in the following figure.

Figure 1. Extended Classification of ESP Domains 


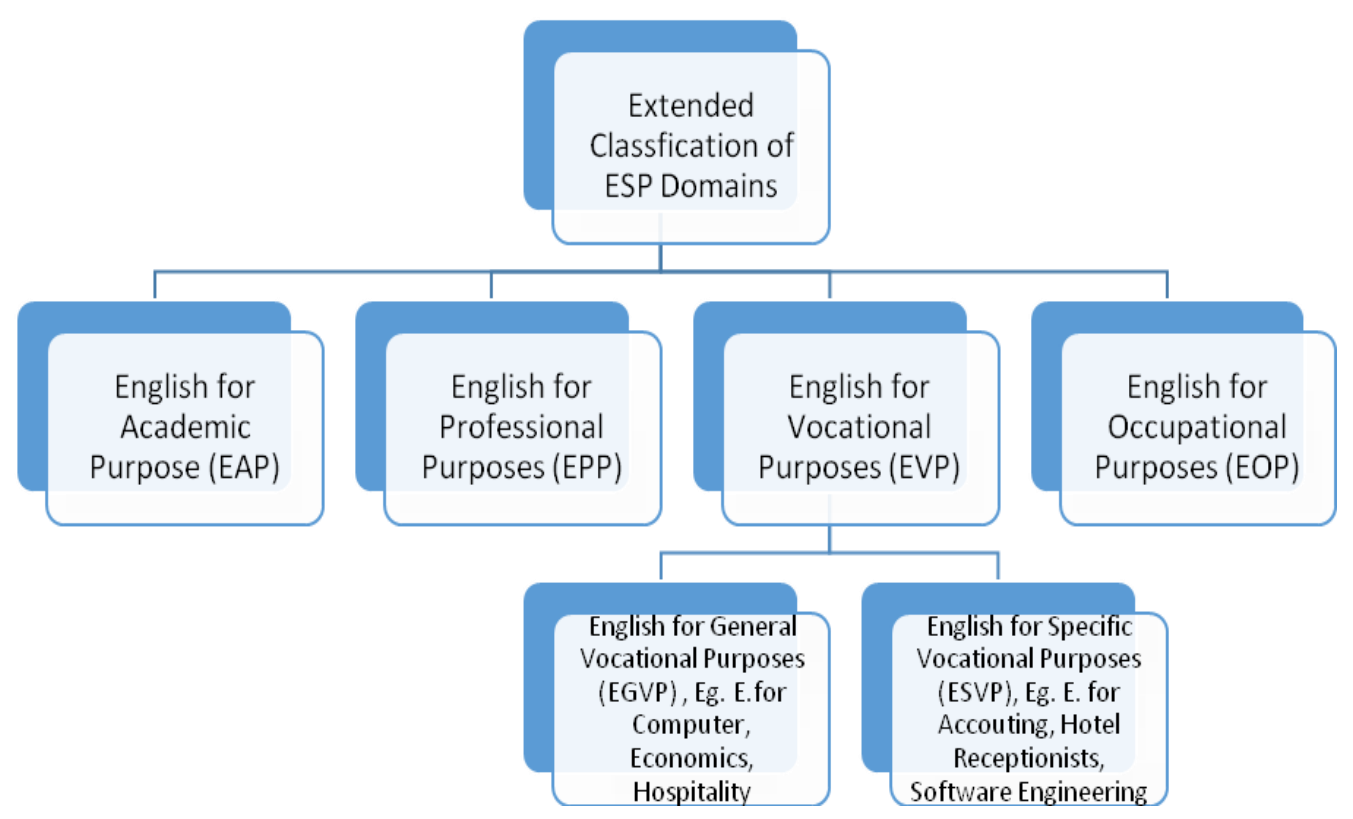

English for Vocational Purpose or Vocational English is viewed as a program socio-institutionally situated in the secondary education sector; Vocational English is designed for students who have a particular vocational interest. Depending on student choice of specialization, English Vocational Purpose is the point of departure for developing EAP, EPP, or EOP competences as students continue their studies into higher education programs. Taken together, the ESP domains are grouped into four major branches: academic, professional, vocational, and occupational. In particular, EV is designed to meet the English language needs of learners in a myriad of specializations, in which these learners prepare both for immediate employment and for higher education either at college or university or polytechnics. This suggests that vocational pathways enhance interconnectedness between education and employment and between secondary education and relevant higher education by showing vocational learners which sectors best match their strengths and support them to identify their strengths. In other words, vocationally-oriented pathways help learners see how their strengths, interests, and talents related to study and employment possibilities. Currently, VE is also a major trend addressing the integration of language learning and vocational learning for learners across vocations. In the context of VOLL, it is also an ESP-based language approach. This program can be characterized by (a) the specificity of vocational (disciplinary) language coupled with general (commonsense) language; (b) the relevance of vocational knowledge; (c) the centrality of vocational discourses; and (d) specificity of vocational activities or tasks. Both culture and identity are socially embedded.

Vocational programs provide further impetus for VOLL in that English programs are designed to address vocational knowledge. This vocational knowledge provides contextual input for using English. In this way, knowledge is constructed with language. Thus, VOLL programs address what vocational texts 
in English are commonly used, and enhance awareness of how the language characterizes these texts. The programs also respond to existing contextual realities and priorities, thereby helping most learners feel that their English learning efforts are worthwhile (Hua and Beverton, 2013: 102). This implies that English is not only seen as a required subject, but also as a tool for making sense of vocational knowledge and for participating in particular vocational discourse communities.

\section{TOPIC-BASED ESP MATERIALS FOR VOCATIONAL SCHOOL}

Materials selection, adaptation, or writing is an important area in ESP teaching,representing a practical result of effective course development and providingstudents with materials that will equip them with the knowledge they will need intheir future business life.Choosing ESP materials determines the running of the course and underlines content of the lesson. Good material should help teacher in organizing the course or what is more it can function as an introduction into the new learning techniques, and support teachers and learners in the process of learning.

One of the most important issues regarding ESP materials selection and/or writing iswhether the materials selected should be solely or primarily subject specific and whatthe most appropriate ratio of general materials to subject-specific materials is. General materials focus on one's general ability to communicate more effectively, while subject-specific materials focus on a particular job or industry (Ellis andJohnson, 1994). When carefully selected, both general and subject-specific materialswill equip the students with the necessary skills and knowledge, but subject-specific materials nevertheless better cater for ESP learners' specific needs. Consequently, ESP learners will very often feel more affinity for materials that they find relevant to their area of specialism. The use of subject-specific textbooks is also more in line with the realization that students are individuals with different needs, styles, and interests and with some central traits of cognitive theory, which, as Skela points out are the following (2008: 159).

1. It focuses on purposeful learning;

2. The learner is seen as an active processor of information;

3. Learning is the process by which the learner tries to make sense of theinformation by imposing a meaningful interpretation or pattern on it;

4. One of the basic teaching techniques is problem-solving;

Recently it has been associated with a focus on deliberate acquisition of alanguage as a logical system;

The importance of carefully selected rules, which can provide an importantshortcut in learning process.

\section{REFERENCES}

Basturkmen, H. (2010). Developing courses in english for specific purposes. New York: Palgrave Macmillan. 
Brinton, D., Snow, M., \& Wesche, M. (1989). Content-based second languageinstruction. New York: Newbury House.

Brown, H.D. (2001). Teaching by principles: An interactive approach to language pedagogy, Second Edition. London: Pearson -Longman.

Budianto, L. (2003). Developing the english syllabus for the students of nursing academy in muhammadiyah university of malang. Malang: IKIP Malang.

Carver, D. (1983). Some propositions about ESP. The ESP Journal, 2, 131-137.

Dudley-Evans, T \& M. St. John. (1998). Developments in English for specific purposes: A multidiciplinary approach. Cambridge: Cambridge University Press.

Ellis, M. and C. Johnson (1994). Teaching business english. Hong Kong: Oxford University Press.

Gage,J., \& Prince, D. (1982). Vocational english: Preparing for a first Job. TESOL Quarterly, 16, 349-358.

Hua, T.L., \& Beverton, S. (2013). General or vocational english courses for taiwanese students in vocational high school? students' perceptions of their english courses and their relevance to their future career. Educational Research for Policy and Practice, 12, 101-120.

Hutchinson, Tom \& Waters, Alan. (2008). English for specific purposes: A learning-centred approach. Cambridge: Cambridge University Press.

Menteri Pendidikan dan KebudayaanRepublik Indonesia. (2013). Peraturan menteri pendidikan pendidikan dan kebudayaan republik indonesia nomor 70 tahun 2013 tentang kerangka dasar dan struktur kurikulum sekolah menengah kejuruan/madrasah aliyah kejuruan.

Kemendikbud. (2012). Dokumen kurikulum 2013. Kementerian Pendidikan dan Kebudayaan.

Kemendikbud. (2013). Kurikulum 2013 kompetensi dasar SMK/MAK. Jakarta: KementerianPendidikan dan Kebudayaan.

Lewis, M. and J. Hill (2003). Source book for teaching english as a foreign language. Hong Kong:Macmillan Publishers Limited.

Platt, E. (1996). The vocational clasroom: A great place to learn english. Washington, D.C.: Center for Applied Linguistics.

Schippers, Uwe, \& Patriana, Djadjang Madya. (1994).Pendidikan kejuruan di Indonesia: Angkasa.

Vogt, K., \& Kantelinen, R. (2013). Vocationally oriented language learning revisited. ELT Journal, 67 (1), 62-69. 
Wallace, Catherine. (1992). Language teaching: A scheme for teacher education. Oxford:Oxford University Press.

Widodo, H.P. (2014). Contextually flaming the design of esp materials: Vocational english reading tasks.In H. Emery \& N. Moore (Eds.), Teaching, learning and researching reading in efl (pp.140-163). Dubai, UAE: TESOL Arabia.

Yuana, Tri, \& Kurniasih, Esti. (2013). An analysis on the learners' needs of english for specific purposes atsmk tri guna bhakti surabaya.Retain, 1(3). 